\title{
Tubular spinae are long-distance connectors between bacteria
}

\author{
M. E. BAYER ${ }^{1 *}$ and K. EASTERBROOK ${ }^{2}$ \\ ${ }^{1}$ Fox Chase Cancer Center, 7701 Burholme Avenue, Philadelphia, PA 19111, USA \\ ${ }^{2}$ Department of Microbiology, Dalhousie University Medical School, Halifax, Nova Scotia, Canada
}

(Received 2 November 1990; revised 5 February 1991; accepted 6 February 1991)

\begin{abstract}
The marine pseudomonad D71 (NCMB 2018) ['Spinomonas maritima'] can be induced to produce long tubular surface appendages (spinae) in a growth medium of low osmolarity. In general, spina-carrying cells show these appendages with open distal ends. We examined cultured cells by scanning and transmission electron microscopy, using both critical-point drying and thin sectioning after embedding with agarose protection. By scanning electron microscopy, spinae were observed that connected cells over distances of several micrometers. Ultrathin sections often revealed an additional layer outside the outer membrane, resembling an S-layer. The inner and outer cell membranes were often joined at spina-insertion areas. Furthermore, evidence was found in ultrathin sections for uninterrupted tubes connecting two cells over a distance of up to $7 \mu \mathrm{m}$. We propose, therefore, that spinae form the framework for wide open cell clusters; we hypothesize that these spinae might also permit an exchange of cell-tocell signals.
\end{abstract}

\section{Introduction}

'Spinomonas maritima' D71 is a Gram-negative marine pseudomonad capable of producing hollow, tubular appendages termed spinae (McGregor-Shaw et al., 1973; Easterbrook \& Coombs, 1976). In contrast to a number of other spina-producing organisms, spina production of Spinomonas maritima is controlled by growth parameters. The highest yield of spinae occurs at a relatively low salt concentration of the medium $(0 \cdot 1 \mathrm{M}-\mathrm{NaCl})$, an elevated temperature $\left(34^{\circ} \mathrm{C}\right)$ and a $\mathrm{pH}$ of 7.4 , whereas growth at $22^{\circ} \mathrm{C}$ and $\mathrm{pH} 6.8$ in $0.4 \mathrm{M}-\mathrm{NaCl}$ generates cells with very few or no spinae (Easterbrook \& Sperker, 1982). Cell envelope preparations of spined cells contain a $42 \mathrm{kDa}$ spinin-specific protein in addition to two other proteins found in whole-cell preparations (Hoyle \& Easterbrook, 1986). It has been estimated that a cell contains about $2.5 \times 10^{5}$ spinin molecules (Easterbrook \& Sperker, 1982); this constitutes a significant portion of the total protein of a spina-producing bacterium. Spinae are structurally associated with the outer membrane. An average of 10 spinae per cell was counted, by Easterbrook \& Sperker (1982), the spinae being 1-3 $\mu \mathrm{m}$ long and $50-70 \mathrm{~nm}$ in diameter. The spinae of marine pseudomonad D71 are characterized by a widening of their tubes at the sites of attachment to the outer

Abbreviations: IM, inner membrane; OM, outer membrane. membrane. We used this feature to identify an insertion area. Electron microscopy of the spinae revealed an arrangement of subunits forming a helix with a shallow pitch of protein filaments, approximately $11 \mathrm{~nm}$ in width. This feature gives the spinae the typical, ribbed appearance that is visible in ultrathin sections, in negatively-stained and in freeze-etched preparations.

The functional role(s) of spinae has been the subject of speculation. In the electron microscope, the distal ends of the spinae appear as open tubes. We hypothesized that under in vivo conditions, these tubes might represent connectors between neighbouring cells, and that conventional preparation procedures would break spinae and disrupt the putative cell-cell connections. In the following we provide evidence that spinae do indeed form connectors several micrometers in length between cells. Thus, spina-carrying cells are capable of generating a three-dimensional array of interconnected bacteria.

\section{Methods}

The marine pseudomonad D71 (NCMB 2018) ['Spinomonas maritima'] was from the culture collection of the Department of Microbiology, Dalhousie University Medical School, Halifax. Cells were grown at 20$27^{\circ} \mathrm{C}$ in liquid cultures in Falcon flasks without shaking. Spinaproducing medium contained $0.1 \mathrm{M}-\mathrm{NaCl}, 0.01 \mathrm{M}-\mathrm{CaCl}_{2}, 0.01 \mathrm{M}-\mathrm{KCl}$, $0.05 \mathrm{M}-\mathrm{MgSO}_{4}, 0.5 \%$ bacto-peptone and $0.1 \%$ yeast extract (both Difco). $\mathrm{CaCl}_{2}$ was prepared separately as a $1 \mathrm{M}$ stock solution. The $\mathrm{pH}$ was adjusted to 7.4 with $10 \mathrm{M}-\mathrm{NaOH}$ before sterilization by autoclave. 
(a)

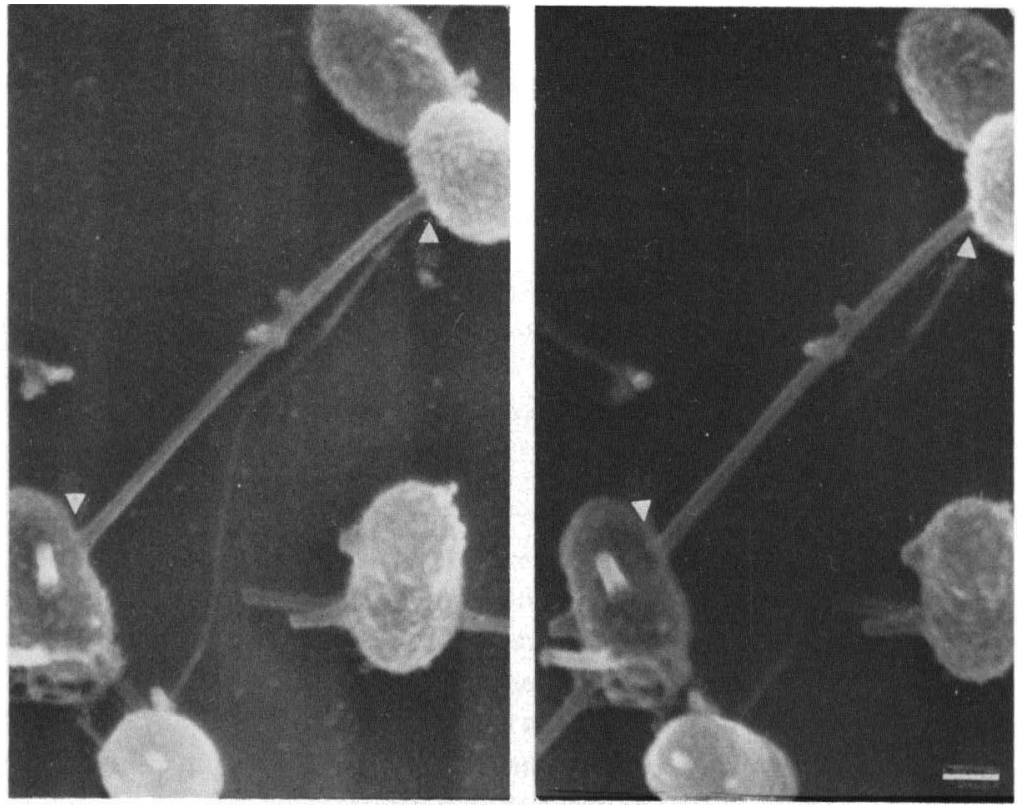

(b)

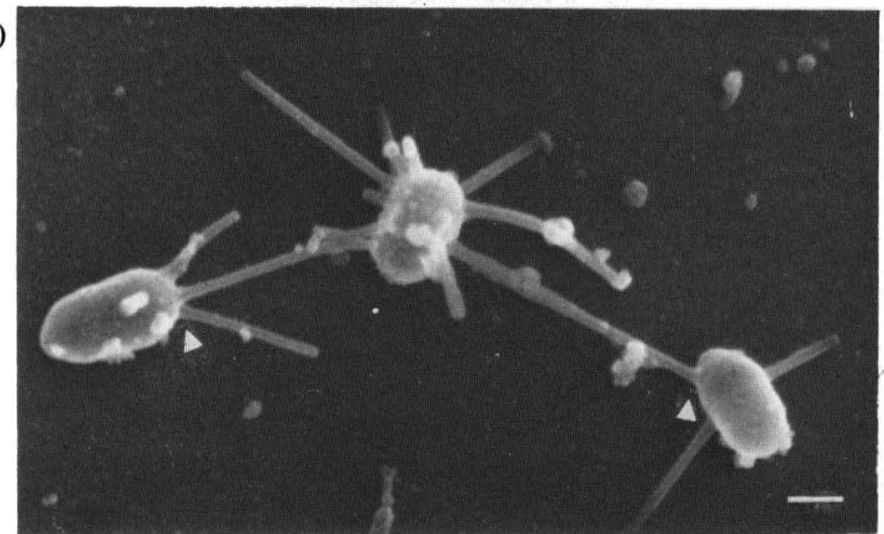

Fig. 1. Scanning electron micrographs of critical-point-dried spina-producing marine pseudomonad D71. The micrographs show that most of the spinae are broken. In $(a)$, a stereo micrograph, two cells are connected by an intact spina. Note the conical insertion bases at the cell surface (arrowheads); in the background a flagellum is visible. In $(b)$ three cells are connected by two spinae. The bar in this and the subsequent micrographs represents $0 \cdot 25 \mu \mathrm{m}$.

The medium had an osmolarity of 320 mosm. For un-spined growth, the $\mathrm{NaCl}$ concentration was increased to $0.4 \mathrm{M}$ and the $\mathrm{pH}$ lowered to 6.8 ; this medium had an osmolarity of 945 mosm. Osmolarities were determined in an Osmette Osmometer (Precision Systems, Natick, MA, USA).

To check for the presence or absence of spinae, cells at densities of $5 \times 10^{7}$ to $2 \times 10^{8} \mathrm{ml}^{-1}$ were inspected in the electron microscope. For transmission electron microscopy, cells were harvested by gentle centrifugation $(600 \mathrm{~g}, 5 \mathrm{~min})$, then fixed for $1 \mathrm{~h}$ in mixtures of glutaraldehyde $(0.5 \%)$ and formaldehyde $(2 \%)$, followed by two washes in growth medium and $60 \mathrm{~min}$ fixation in $1 \% \mathrm{OsO}_{4}$ in $0.1 \mathrm{M}$-potassium phosphate buffer, pH 7-2. After fixation, a number of specimens were exposed for $60 \mathrm{~min}$ to $1 \%(\mathrm{w} / \mathrm{v})$ tannic acid in $0.1 \mathrm{M}$-cacodylate buffer pH 7.2. After stepwise dehydration in ethyl alcohol, embedding was performed in Epon 812. To avoid the mechanical stress of centrifugation, we also grew cells in a glass tube, at $28^{\circ} \mathrm{C}$ in $2 \%(w / v)$ Seaprep agarose (FMC BioProducts) containing the growth medium. After 2-3 d, the growing cultures were cooled to $4{ }^{\circ} \mathrm{C}$ and the gels were transferred to cold fixation medium and prepared for Epon embedding as described above. Ultrathin sections were obtained in a Sorval MT2 ultramicrotome and were stained with uranyl acetate $(0.5 \%)$ and lead citrate. In some cases, $2 \%(\mathrm{w} / \mathrm{v})$ ruthenium red (EM Sciences, Fort Washington, PA, USA) was used as section stain before the uranyl and lead stain. Micrographs were obtained in a Philips 420 transmission electron microscope. For scanning micrographs, specimens from liquid cultures were attached to polylysine-treated glass, fixed as described above, dehydrated in acetone, transferred to amyl acetate and criticalpoint dried in $\mathrm{CO}_{2}$. They were shadow-cast with $\mathrm{Pt}$ on a rotating stage of a vacuum evaporator (Denton) and inspected with an ETEC autoscan.

\section{Results}

Marine pseudomonad D71 was grown aerobically in liquid medium at $26-28^{\circ} \mathrm{C}$ for $3 \mathrm{~d}$. At that time the cell number (counted by phase-contrast microscopy) had 

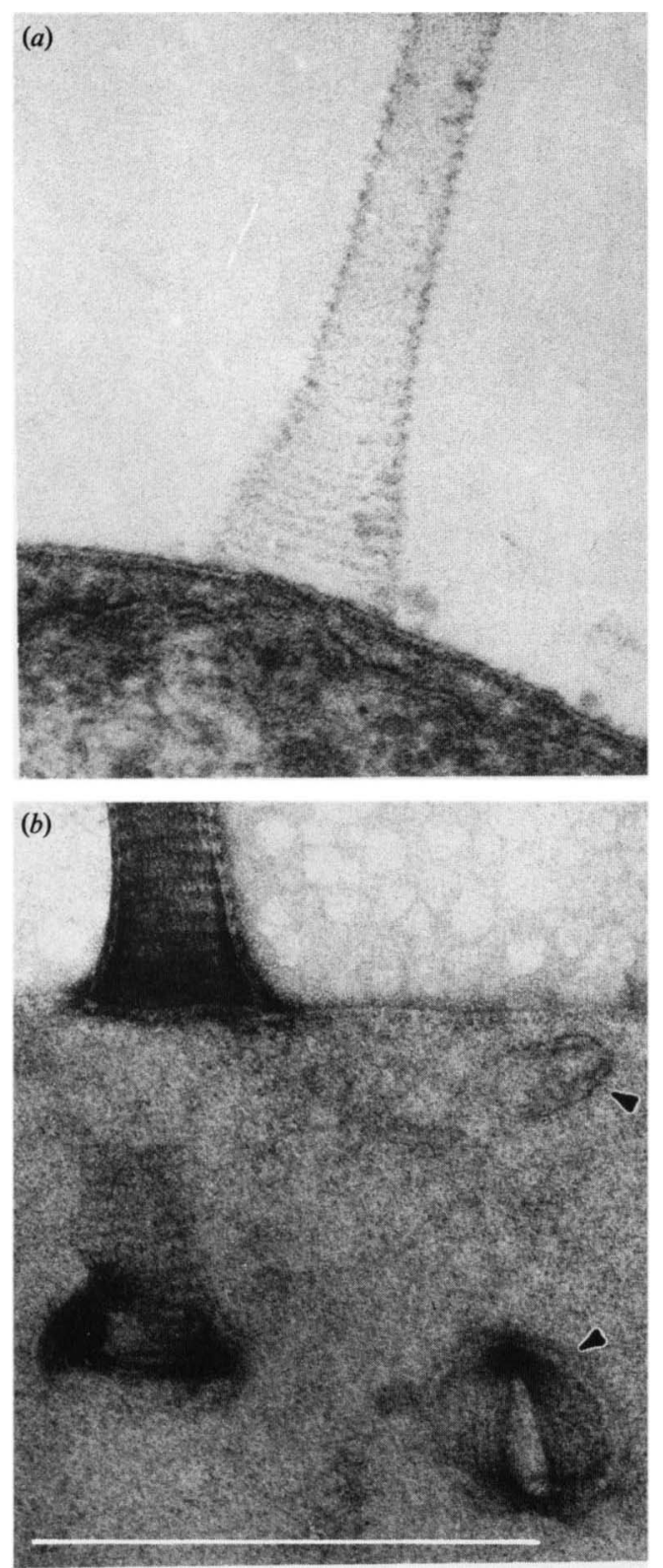

Fig. 2. Spina attachment to cell surface. (a) Ultrathin section; (b) negative stain. Arrowheads indicate the 'scars' in the OM.

reached approximately $5 \times 10^{8} \mathrm{ml}^{-1}$. During the period of growth, the culture fluid became increasingly turbid and a white sediment of cells formed at the bottom of the shallow culture flasks. There seemed to be no adhesion to the culture vessel and the slightest stirring, such as tilting of the flask, led to a cloud-like re-suspension of the sediment of both un-spined and spined cultures. When cells from spina-producing cultures were cautiously removed from the culture flask with a platinum loop and negatively stained, the spinae were clearly visible by TEM; most of them ended abruptly in the medium. Only in a few cases could uninterrupted spinae be observed.

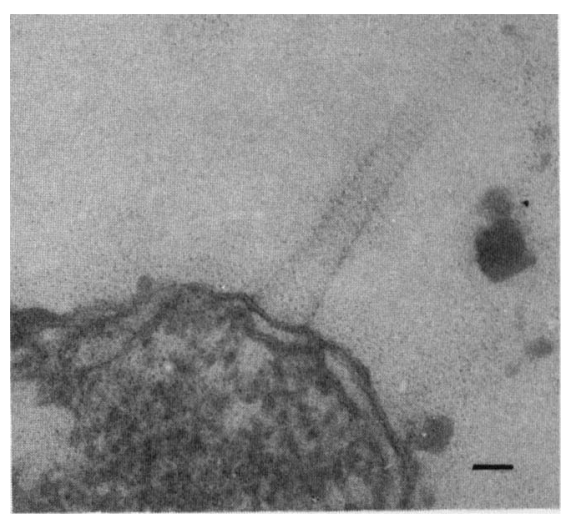

Fig. 3. Ultrathin section revealing contacts of the IM with the OM near (or at) the periphery of the conical base of a spina.

These spinae were seen to form cell-cell connections. Almost all micrographs showing a clear view of the spina insertion area at the cell surface revealed a widening at the tubular base. Using this as a marker, we considered a cell-cell connection via a spina to be 'true' whenever an undisrupted connecting spina showed a conical widening of the tubular diameter at both insertion areas (at the cell surfaces). However, we cannot fully exclude the possibility that stable contacts may in rare instances be made without the conical widening at insertion sites.

Scanning electron microscopy of critical-point-dried specimens also revealed connecting tubes (Fig. $1 a, b$ ). Here, again, almost all of the spinae ended freely, as if broken. In several cases, however, cells were seen to be connected by spinae: two connected cells are shown in Fig. 1 (a) (a stereo micrograph), with a widening at each insertion site (arrowheads). A cluster of three cells is shown in Fig. $1(b)$. Here, each cell is connected to its neighbour(s) by one long spina. The other spinae are broken off, and point in various directions as demonstrated by the stereo view. In most cases, one of the insertion sites in such preparations was obscured either by the curvature of the cell surface or by other spinae. Therefore, specimen tilt and rotation was regularly used to inspect the attachment area in question. Unfortunately, the necessary tilt or rotation was often of such a magnitude that simultaneous stereo viewing of both insertion sites of one pair (as in Fig. $1 a, b$ ) could rarely be achieved.

The areas of attachment of spinae to the cell surface, namely to the outer membrane (OM) contour, are clearly defined in ultrathin sections (Fig. 2a). A corresponding area shown in a negatively-stained preparation (Fig. $2 b$ ) depicts a spina in side view. Both micrographs display the typical repeat structure which is caused by the helices of spinin subunits (Coombs et al., 1976) and measured, from helix to helix, $10 \cdot 10 \pm 0 \cdot 46 \mathrm{~nm}$ in ultrathin sections 


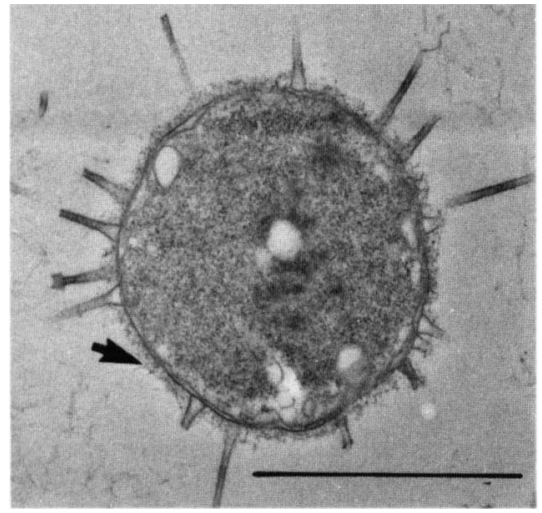

Fig. 4. Multiple spina attachment. The cell surface also shows additional material resembling an S-layer (arrow).

and $11.68 \pm 0.60 \mathrm{~nm}$ in negatively stained preparations. In addition, Fig. 2(b) (arrowheads) shows en-face views of 'scars', areas of spina bases where the spinae might have broken off or where spina growth might have been initiated.

Ultrathin sections also revealed the inner membrane (IM) of the cell envelope. Of special interest was the behaviour of the IM at the area of spina attachment to the OM. In spite of the occasional presence of rather dense material in the periplasm in some of the cells (Fig. $2 a$ ), which was enhanced in contrast after ruthenium red staining, the IM was clearly visible (Fig. 3) and exhibited a slightly undulating contour. Serial sections and stereo micrographs of single sections revealed that for short distances the IM seemed to come close to the OM within the domain of the spina base; however, an extended IMOM contact encompassing the entire base of the spina insertion has not been observed. We found that a close IM-OM contact often occurred in a pair of small areas more or less in register with the periphery of the base of a spina (Fig. 3). To observe these arrangements, a slight plasmolysis is required, in addition to a feasible section plane. Such a degree of plasmolysis is automatically introduced in most cells by the presence of the fixative, which adds 60 mosm for $0.5 \%$ glutaraldehyde and 800 mosm for $2 \%$ formaldehyde.

Since ultrathin sections of conventionally-prepared specimens showed only spinae which ended abruptly, we grew cells in an agarose (Seaprep) which was liquid at $28^{\circ} \mathrm{C}$ and capable of forming a gel at temperatures below the growth temperature of the cell culture. During growth in Seaprep, the cells formed visible precipitates that settled at or near the bottom of the culture tube. When these cultures were immobilized by cooling the Seaprep to $4{ }^{\circ} \mathrm{C}$, and the gel was subsequently fixed, dehydrated, Epon-embedded and sectioned, very long spinae were observed. Many of them appeared to aim

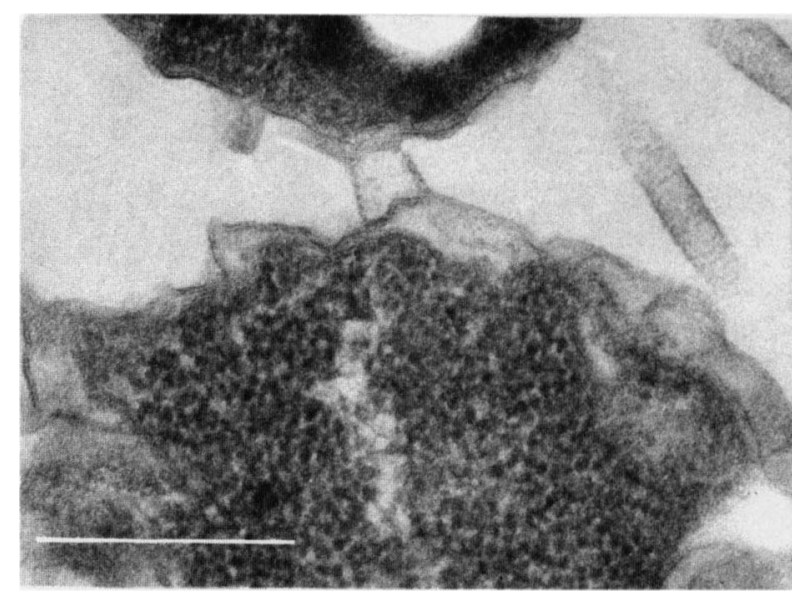

Fig. 5. A very short spina connection between two neighbouring cells.

towards neighbouring cells. Individual cells often exhibited an astonishing amount of spinae; Fig. 4 shows a sectioned cell with numerous spinae protruding from its OM. It became obvious during this study that spinaconnected cells could only rarely be expected to be positioned in such a way that the very thin $(0.05 \mu \mathrm{m})$ plane of an ultrathin section would enclose a full-length tubular spina with both ends attaching to nèighbouring cells. Since cell clusters growing in agarose are widely separated (the cells were not subjected to centrifugation), search for cell groups in serial sections did not appear to provide us with better yields of cell-cell connections than did single sections. While searching for cell pairs, we observed in a few cases very short spinae, possibly also forming cell-cell bridges (Fig. 5). Such an arrangement might indicate the development of an intercellular connection. To prevent 'false' interpretations, most micrographs of spinae that appeared to connect two cells were taken as stereo pairs. Using this method, we had to exclude a large number of cell pairs, since their spinae did not fulfil our requirement of showing a widened base at the cell surface or, most often, the incoming spina was aligned so that it touched the uneven cell surface only tangentially. It sometimes also happened that spinae, each of them originating from a cell, and showing a conical base, appeared to be one and the same tube, as viewed from one direction. However, stereo tilt permitted us to identify, in these cases, two separate spinae, aligned on top of each other, but not connected with each other. Most telling was an ultrathin section (Fig. 6) in which two cells were connected with a long spina. The bases of the spina appear to have the proper widening of the tube at the attachment sites to the cells.

The surface of many, but not all, cells revealed additional particulate material beyond the OM (Fig. 4). We found that in grazing sections, particulate elements of this layer were spaced (centre to centre) approximately 


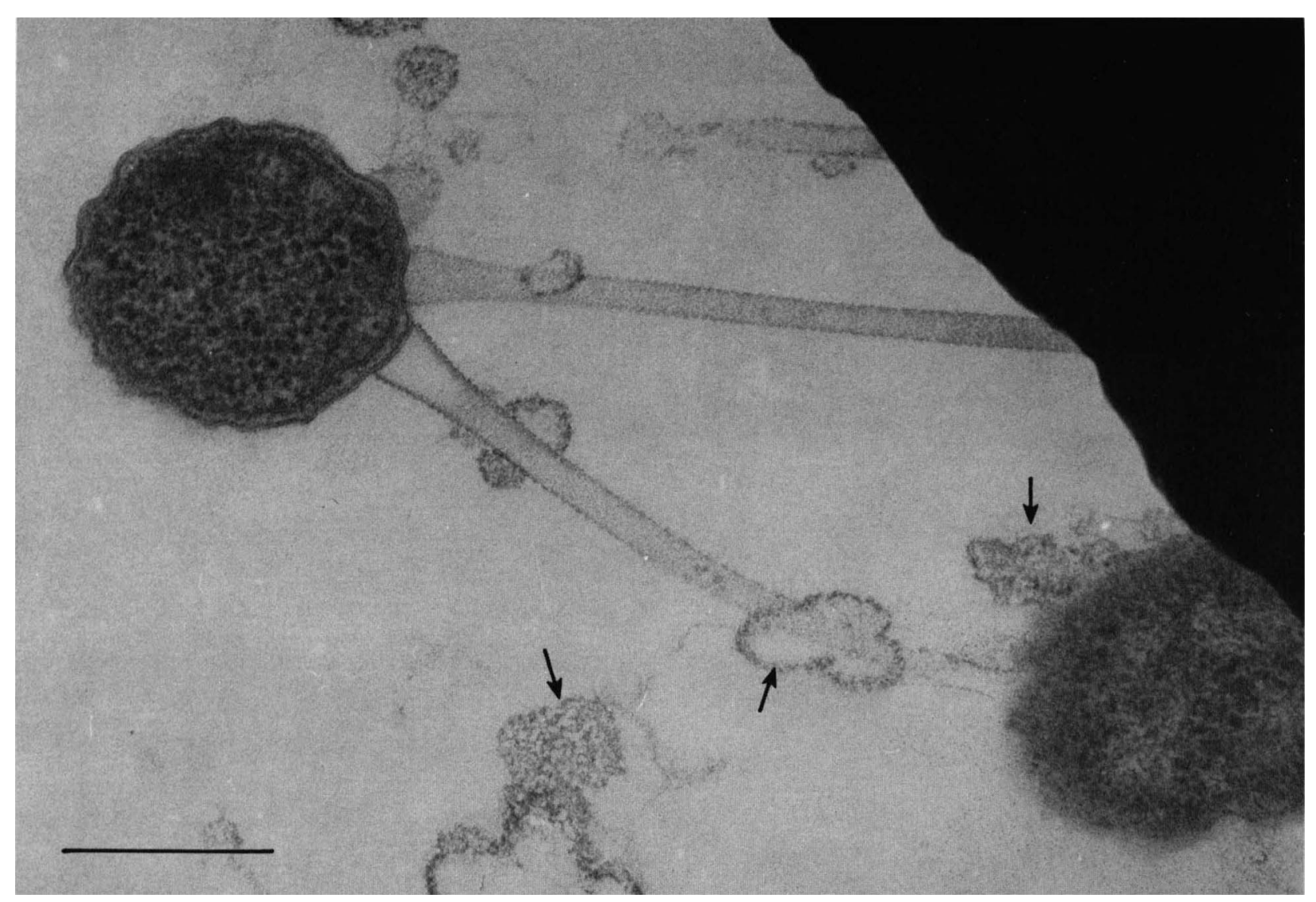

Fig. 6. A rare micrograph of one long spina connecting two cells. Note the widening base of the spina at each of the sites of attachment to the cells' surfaces. Arrows point to cell surface material possibly representing detached remnants of an S-layer.

$13 \mathrm{~nm}$ apart. The arrangement did not show any sign of highly ordered arrays. Frequently a granular, vesicular material was visible (Fig. 6, arrows) which formed a loose association with cells and spinae and was also seen to be seemingly unattached. We assume that this substance represents envelope material, possibly an Slayer, which partially detaches from cells during the preparation steps and becomes trapped in the agarose.

\section{Discussion}

Spinae have been considered to play a role in cell sedimentation and protection from protozoal predation (Easterbrook \& Sperker, 1982). Since a major portion of protein synthesis is involved in the synthesis of spinae, their production is most likely of considerable significance to the biology and survival of the organism. To our knowledge, this is the first demonstration of a cell-cell connection in which spinae are used. The sites of spinin synthesis and transmembrane export are not known.
Some of the micrographs (Fig. 3) reveal contact areas of IM and OM. If these areas are homologous to 'adhesion sites' of enterobacteria (Bayer, 1981), their relatively small contact area would suggest a model in which the sites of protein export at the IM are moving and temporarily disconnecting around the base of a spina. Since spinae grow from their tips, the translocation of subunits through the $\mathrm{OM}$ at the base of a spina would be followed by diffusion of the subunits toward the tip of the tube. We hypothesize that the tubular system, when connecting neighbouring cells, makes it possible to generate large clusters in which bacteria are joined over distances of many micrometers. If these clusters were settling in the fine silt of brackish water of estuaries and tidal pools, the hollow spinae would allow for open unobstructed tubular connections between individual cells. The mechanisms(s) of generating the connections between cells is unclear. It is possible that in dividing cells the spina base is split into two sites which keep the tube extension in phase with the increasing distance between the separating daughter cells. An early phase 
with a very short tube might be represented in Fig. 5. However, separated or broken ends of longer tubes might also have the capability to 'dock' with each other: after an end-to-end collision the helices could be joined at the tips by lining up and polymerizing their spinin helices. An important question remains unanswered, namely, whether the spinae are used solely for maintaining a certain distance from neighbouring cells (which could, however, be achieved with less expense of energy, for example by the use of capsular material), or whether they might indeed be involved in cell-to-cell communication. This would unite a group of single cells into a unique type of multicellular organism.

The dedicated assistance of S. Shepardson in providing many of the ultrathin sections is acknowledged. The work was supported by Public Health Service grants RR-05539 and CA-06927 from the National Institute of Health; DCB-85-03684 from the National Science Foundation; and an appropriation from the Commonwealth of Pennsylvania. We thank Mrs A. Capriotti and Mrs J. Ford for typing the manuscript. Some of the data were reported at the 39th Annual Meeting of the Canadian Society of Microbiologists, Laval, 1989.

\section{References}

BAYER, M. E. (1981). Structural and functional evidence of cooperativity between membranes and cell wall in bacteria. International Review of Cytology 12, 39-70.

CoOmbs, R. W., Verpoorte, J. A. \& Easterbrook, K. B. (1976). Protein conformation in bacterial spinae. Biopolymers 15, 23532369.

EAsterbrooK, K. B. \& COOMbS, R. W. (1976). Spinin: the subunit protein of bacterial spinae. Canadian Journal of Microbiology 22, 438440.

Easterbrook, K. B. \& Sperker, S. (1982). Physiological controls of bacterial spinae production in complex media and their value as prediction of spina function. Canadian Journal of Microbiology 28 , $130-136$.

HOYLE, B. D. \& EASTERBROOK, K. B. (1986). Electrophoretic studies on the cell envelope of a spina-producing pseudomonad. Canadian Journal of Microbiology 32, 901-908.

McGregor-Shaw, J. B., EASterbrook, K. B. \& McBride, R. P. (1973). A bacterium with echinuliform (nonprosthecate) appendages. International Journal of Systematic Bacteriology 23, 267-270. 